\title{
Sınıf Öğretmenlerinin ve Öğrencilerinin Matematik Kaygı Puanları Arasındaki İlişkinin Bazı Değişkenlere Göre İncelenmesi ${ }^{1}$
}

Sevgi Yavuz ${ }^{2}$

Type/Tür:

Research/Araştırma

Received/Geliş Tarihi: April

27/ 27 Nisan 2020

Accepted/Kabul Tarihi:

October 26/ 26 Ekim 2020

Page numbers/Sayfa No: 392-

416

Corresponding

Author/İletişimden Sorumlu

Yazar: ozkaya42@gmail.com

\section{$\checkmark$ iThenticate}

This paper was checked for plagiarism using iThenticate during the preview process and before publication. / $\mathrm{Bu}$ çalışma ön inceleme sürecinde ve yayımlanmadan önce iThenticate yazılımı ile taranmıştır.

\section{Copyright $@ 2017$ by}

Cumhuriyet University, Faculty of Education. All rights reserved.

\section{Ali Özkaya ${ }^{3}$}

\section{Öz}

Matematik öğretiminde/öğreniminde yaşanan problemlerden biri de matematik kaygısıdır. Bu araştırmanın amacı, sınıf öğretmenlerinin ve öğrencilerinin matematik kaygı puanlarını çeşitli değişkenler açısından incelemek ve sınıf öğretmenleriyle öğrencilerinin matematik kaygıları arasında ilişki olup olmadığını analiz etmektir. Araştırma, korelasyonel bir çalışma olarak tasarlanmıştır Araştırmanın örneklemini, 2018-2019 eğitim öğretim yılı, Antalya İli, Kepez İlçesi, Milli Eğitim Bakanlığı'na bağlı devlet okullarının 3 ve 4 . sınıfını okutan sınıf öğretmenleri ve bu öğretmenlerin ders verdikleri 3 ve 4 . sınıf öğrencileri oluşturmuştur. Araştırmanın verilerini toplamak için Öğretmen Matematik Kaygi Ölçeği, Öğrenci Matematik Kaygı Ölçeği ile Kişisel Bilgi Formu kullanılmıştır. Araştırma verilerinin çözümlenmesinde, frekans, yüzde, ortalama, standart sapma, normallik testi istatistik hesaplamaları kullanılmıştır. Sınıf öğretmeni ve öğrencilerinin çeşitli değişkenler açısından kaygı puanlarında anlamlı bir fark olup olmadığını belirlemek için İlişkisiz Örneklemler t-Testi, Tek Yönlü Varyans Analizi ve post hoc Tukey Testi ile analizler yapılmıştır. Sınıf öğretmenlerinin kaygı puanları ile öğrencilerinin kaygı puanlarının ilişkisel anlamlılığını belirlemek için Pearson Momentler Korelasyon Analizi kullanılmıştır. Yapılan analizler sonucunda 4. sınıf öğretmenlerinin kaygı puanlarının 3. sınıf öğretmenlerine göre daha yüksek olduğu görülmüştür. Öğretmenlerin matematik kaygı puanlarıyla kıdemleri arasında anlamlı bir ilişki saptanmıştır. Öğrencilerin matematik kaygı puanları, düşük seviyede bulunmuştur. Yine yapılan analiz sonucunda, sınıf öğretmenleri ile öğrencilerinin matematik kaygı puanları arasında anlamlı bir ilişki olduğu tespit edilmiştir. Alt faktörlere bakıldığında sınıf öğretmenlerinin ÖzYeterlik Kaygısı ile öğrencilerin Olumsuz Tutum faktörü arasında anlamlı bir ilişki hesaplanmıştır. Ayrıca sınıf öğretmenlerinin Matematiksel İletişim Kaygısı ve Toplam Kaygı puanları ile öğrencilerin ÇekinmeEndişelenme faktörü arasında anlamlı bir ilişki saptanmıştır.

Anahtar Kelimeler: Kaygı, matematik kaygısı, cinsiyet, öğretmen matematik kaygısı, öğrenci matematik kaygısı

\section{Suggested APA Citation/Önerilen APA Atıf Biçimi:}

Yavuz, S., \& Özkaya, A. (2021). Sınıf öğretmenlerinin ve öğrencilerinin matematik kaygı puanları arasındaki ilişkinin bazı değişkenlere göre incelenmesi Cumhuriyet International Journal of Education, 10(1), 392-416. http://dx.doi.org/10.30703/cije.727597

\footnotetext{
${ }^{1}$ Bu çalışma birinci yazarın “Sınıf öğretmenlerinin matematik derslerindeki kaygı düzeyleri ve öğrencilerin matematik kaygı düzeyleriyle ilişkisi” adlı yüksek lisans tezinden üretilmiştir.

2 Öğretmen, Milli Eğitim Bakanlığı, Antalya/Türkiye

Teacher, The Ministry of Education, Antalya/Turkey

e-mail: sevgi.antalya@gmail.com ORCID ID: orcid.org/0000-0002-4933-3776
}

${ }^{3}$ Dr. Öğr. Üyesi, Akdeniz Üniversitesi, Matematik ve Fen Bilimleri Eğitimi Bölümü, Antalya/Türkiye Asst. Prof. Dr., Akdeniz University, Department of Mathematics and Science Education, Antalya/Turkey e-mail: ozkaya42@gmail.com ORCID ID: orcid.org/0000-0002-6401-1839 


\title{
Investigation of Mathematic Anxiety Scores of Class Teachers and Their Students' According to Some Variables
}

\begin{abstract}
One of the problems experienced in teaching/learning mathematics is math anxiety. The aim of this study is to investigate math anxiety levels of classroom teachers and their students in terms of various variables and to analyze whether there is a statistically significant relationship between math anxiety of classroom teachers and their students. The research was designed as a correlational study. The sample consist of $3 \mathrm{rd}$ and 4 th classroom teachers and their students in Antalya Province in the academic year 20182019. The Teacher Anxiety Scale, the Personal Information Form and Mathematics Anxiety Scale are used as data collection tools. In analyzing the research data, frequency, percentage, average, standard deviation, normality test were used. In order to determine whether there is a significant difference in the anxiety scores of the classroom teachers and their students' in terms of various variables, analyzes were done with the Unrelated Samples t-Test, One Way ANOVA Test, Post Hoc Tukey Test and Pearson Moments Correlation Analysis. As a result of the analysis, it was seen that anxiety scores of 4th grade teachers were higher than 3 rd grade teachers. There was a significant relationship between teachers' math anxiety scores and seniority. There was a significant relationship between teachers' math anxiety scores and age and seniority. Students' math anxiety scores were found to be low. As a result of the analysis, it was found that there was a significant relationship between mathematics anxiety scores of classroom teachers and students. When the sub factors are analyzed a significant relationship was calculated between the teachers' self-efficacy anxiety and the students' negative attitude factor. In addition, a significant relationship was found between the mathematical communication anxiety and total anxiety scores of the classroom teachers and the students' wince-worry factor.
\end{abstract}

Keywords: Anxiety, math anxiety, gender, math anxiety of teacher, math anxiety of student

\section{Giriş}

Matematik, bilim, teknoloji, sanayi ve ekonomik kalkınma gibi gelişim alanlarının temel yapıtaşıdır. Matematiği doğru kullanabilen bir ülke, gelişmiş ülkelerin statüsüne ve refahına yükselebilir (Ersoy, 2003). Matematik kaygısı matematik öğretiminde yaşanan zorlukların başında gelmektedir (Baloğlu, 2001). Bu kaygıya eğitim-öğretimin bütüncül yapısı ve öğretmen yaklaşımlarının etki ettiği belirtilmektedir (Peker ve Ertekin, 2011). Matematik dersi hakkında yapılan araştırmaların pek çoğunda, öğrencilerin, öğretmenlerin hatta öğretmen adaylarının matematik hakkında olumsuz tutuma sahip olabildikleri belirlenmiştir (Baloğlu, 1999; Bourne, 1995; Campbell ve Evans, 1997; Delice, Ertekin, Aydın ve Dilmaç, 2009; Mutlu, Söylemez, 2018; Shields, 2006; Zettle ve Raines, 2000). Kayg1; bireyin kendini tehdit altında ve duygusal çatışmada hissettiğinde, zorlayıcı gücün olduğu bir ortamda, kendini eksik ve yetersiz gördügüünde içinde bulunduğu duygu durumu olarak tanımlanmaktadır (Nolting, 2011; Tobias, 1990). Bireyde, az miktarda olan ve artmayan kayginın daha dikkatli olmayı sağladığı ve başarıyı getirdiği görülürken bireyin hiç kaygı duymaması da başarısızlığa neden olabilmektedir (Scovel, 1978). Üldaş'a (2005) göre matematik kaygısı, öğrenciyi başarısızlığa götüren, öğrencinin yeteneklerini ve becerilerini etkili bir şekilde kullanmasını engelleyen, öz güvenini sarsan, kapasitesini ve gelecek planların olumsuz etkileyen, psikolojik bir durumdur. Öğrencilerin matematiğe karşı duydukları kaygı, onların sayısal alanda öğrenmelerini engelleyen bir duygu 
durumudur (Wilder, 2012; Zopp, 1999). Matematik kayg1sı üzerine yoğunlaşan araştırmalar, zihnin matematikle ilgili bilişsel mekanizmasının olumsuz işleyişe, olumsuz bilişsel işleyişin de matematik kaygısına neden olduğuna ve bunun sonucunda da kişinin çalışma belleğinin düşük performans sergilediğini ifade etmişlerdir (Hembree, 1990).

Matematik kaygısının etkileri, kısa dönemli ve uzun dönemli etkiler olmak üzere iki ana başlıkta toplanmıştır. Matematik kaygısının en belirgin kısa dönemli etkisi; öğrencinin matematik derslerindeki performansının ve başarısının düşmesidir. Uzun dönemli etkileri ise öğrencinin, matematik derslerini sevmemesi, matematik derslerinden çekinmesi, çaresizliği ve zorlanmışlık hissi gibi tutum ve davranışlarda olmasıdır (Baloğlu, 2001). Yenilmez ve Özbey'e (2006) göre, öğrenci matematik dersini başaramayacağını düşünürse ve matematikle ilgili konularla ilgilenmek istemezse, bunun sonucunda zamanla matematik dersine karş1 artan bir kayg1 duyar ve matematik derslerini sevmemeye başlar. Bu kayg1 durumu, henüz anlatılmayan matematik konularına karşı da devam eder ve matematik dersinin tamamına genellenir (McLeod ve Adams, 2012). Bu durumun sonucunda da öğrenci, kendine güvenmeyen, matematiği anlayabilecek beceriye sahip olmadığını düşünen, problemlerden kaçan ve kendi kabiliyetinin farkına varmayan bir birey haline gelebilmektedir. Hannula (2002) bireylerin, okul hayatları boyunca yaşadıkları matematik kaygısından dolayı matematikle ilgisi olmayan bölümleri tercih ettiklerini belirtmiştir. Ashcraft (2002) ise öğrencilerin matematiği başaramayıp, yenilmiş olma yaklaşımıyla meslek seçiminde matematik gerektirmeyen bir ana dal seçerek hayati bir karar almaktadırlar. Bu durum, belki de öğrencilerin başarılı ve mutlu olmayacakları yanlış meslek tercihleri yapmalarına da sebep olmaktadır (Üldaş, 2005).

Öğrencilerin, matematiğe karşı olumsuz yaklaşımlarının nedenleri olarak matematiği başaramama duygusu (Yenilmez ve Özbey, 2006), çabasının farkına varılmaması, aile faktörü, çevresel yaşantılar ve çevrenin bakış açısı (Ashcraft ve Ridley, 2005), okullarda okutulan yıllık ders planı, malzeme kısıtlılığı, matematik derslerinde kullanılan öğretim yöntemleri ve en önemlisi de öğretmenlerin derslerdeki matematiğe karşı olan yaklaşımı sayılabilir (Martinez, 1987). Öğretmenlerin ders esnasında yaptıkları anlatım, iletişim dili, etkinlik ve uygulamalar eğer öğrencileri üzerinde kayg1 oluşturuyorsa bu kaygı, öğretmenden kaynaklanan kayg1 olarak açıklanmaktadır (Gardner ve Leak, 1994). Öğrencilerin sahip olduğu kayg1, matematik dersinde başarılı olmamalarına (Bekdemir, Işık ve Çıkılı, 2004) ve matematiği sevmemelerine neden olur ve bu durumda öğretmen yaklaşımlarının etkisi büyüktür (Delice ve ark., 2009; Vinson 2001). Yıldırım ve Gürbüz (2017) yaptıkları ölçek geliştirme çalışmasında öğrencilerin, öğretmenlerinin tutum ve davranışlarından etkilendiğini ve öğrenci davranışlarının da bu etkiye tepki olarak şekillendiğini belirtmiştir. Bu durumun sonucu olarak öğretmenin alanı ne olursa olsun kendisini rol model alan öğrencileri etkileyeceği, matematiksel tutum ve yaklaşımı olduğu gibi öğrencilerine aktarabileceği ifade edilmektedir. Bundan dolayı, matematik ile ilgili olumsuz tutum ve davranışa sahip bir öğretmenin, matematik konusunda olumsuz bir model oluşturacağı söylenebilir. Bir öğretmen, matematikle ilgili olumsuz bir tutum ve yaklaşıma sahip ise bu durum özellikle ilkokulda, öğretmenini model alan öğrencilerin matematiğe karşı olumsuz yaklaşım geliştirmesine neden olacaktır (Bekdemir, 2007; Harper ve Daane 1998). İlkokul öğretmenlerinin sahip olduğu 
matematik kaygısının, toplumdaki diğer kişilerin sahip olduğu matematik kaygısı ile benzer olduğu ve özellikle öğretmenlerin matematik kaygısının ders anlatırken ortaya çıktığ1 vurgulanmıştır (Wood, 1988).

Matematik kaygısı üzerine yapılan çalışmalarda, geçmişte matematik öğretmenleriyle olumsuz yaşantıları olan kişilerin, sonraki yaşantılarında da matematiğe karşı temkinli ve kaygılı oldukları belirlenmiştir (Perry, 2004). Sınıf öğretmenlerinin öğrencilerine ders içi ve ders dişı olumlu matematik yaklaşım ve becerilerini kazandırabilmeleri çok önemlidir. Bloom'a (1998) göre öğrencinin 18 yaşına kadar gösterdiği başarının \%42'si ilkokuldaki başarı durumuyla açıklanmaktadır. İlkokuldaki öğrenme yaşantılarının, sonraki öğrenmeler ve kazanımlar için temel bir öğretim niteliğinde olduğu açıktır. Matematik kaygısı taşıyan öğretmenlerin, matematiğe yaklaşımı ve matematik öğretimiyle ilgili olumsuz fikir ve davranış taşıdıkları düşünüldüğünde sınıf öğretmenlerinin görev ve sorumluluklarının büyük olduğu açıtır.

Matematik kaygısı ile ilgili araştırmalar daha çok ortaokul öğrencileri, lise öğrencileri ve öğretmen adaylarıyla yapılmıştır (Akgül, 2008; Aydın, Delice, Dilmaç ve Ertekin, 2009; Delice ve ark., 2009; Doruk ve Kaplan, 2012; Elmas, 2010; Gresham, 2008; Kutluca, Alpay ve Kutluca, 2015; Peker, 2009a, 2009b, 2009c; Peker ve Halat 2008; Peker ve Mirasyedioğlu 2003; Tatar, Zengin ve Kağ1zmanl1, 2016; Şentürk, 2010; Taşdemir, 2015; Woodard, 2004). İlkokul öğrencilerindeki matematik kaygısını (Ünlü, 2007; Yenihayat, 2007) ve sınıf öğretmenlerinin matematik kaygısını (Beilock, Gunderson, Ramirez ve Levine, 2010; Sakal, 2015) araştıran çalışmalar ise az sayıdadır. $\mathrm{Bu}$ çalışmada, sınıf öğretmenlerinin ve öğrencilerinin matematik kaygıları bazı değişkenler açısından incelenmiş ve diğer çalışmalardan farklı olarak öğretmenlerin ve öğrencilerin kaygıları arasında korelasyonel ilişkiye bakılmış ve uygun çözüm önerilerinde bulunulmuştur.

\section{Problem Cümlesi}

Araştırmada aşağıdaki sorulara cevap aranmıştır.

- Sınıf öğretmenlerinin matematik kaygı puanlarının;

a) Cinsiyetlerine

b) Okutulan sinif seviyesine

c) Öğretmenin lisans mezuniyet seviyesine

d) Mezun olunan alan değişkenlerine

e) Kıdemlerine göre istatistiksel olarak anlamlı farklılık göstermekte midir?

- İlkokul öğrencilerinin matematik kaygı puanları cinsiyet değişkenine göre istatistiksel olarak anlamlı farklılık göstermekte midir?

- Sınıf öğretmenlerinin matematik kaygıları ile öğrencilerinin matematik kaygıları arasında istatistiksel olarak anlamlı bir ilişki var mıdır?

\section{Yöntem}

Bu araştırma; sınıf öğretmenlerinin matematik kaygılarını ve bu kaygıların çeşitli değişkenlere göre anlamlılı̆̆ını araştırmak, ayrıca öğrencilerin matematik kaygılarını puanlamak ve çeşitli değişkenlere göre anlamlılı̆̆ını belirlemek amacıyla yapılmıştır. Sınıf öğretmenlerinin ve öğrencilerinin matematik kaygıları arasındaki ilişkiyi belirlemeye yönelik tarama modelinde korelasyonel bir çalışma olarak tasarlanmıştır 
(Büyüköztürk, 2012). Tarama modelleri geçmişte veya şu anda var olan durumu olduğu gibi betimlemeyi amaçlayan, insanların tutumları, inanışları, değerleri, alışkanlıkları ve düşünceleri gibi bilgileri olduğu gibi inceleyen araştırma yaklaşımlarıdır (Karasar, 2013).

\section{Çalışma Grubu}

Araştırmanın evrenini 2018- 2019 eğitim-öğretim yılında Antalya İli merkezinde görev yapan 3 ve 4 . sınıf öğretmenleri (530 öğretmen) ve bu öğretmenlerin eğitim-öğretim verdikleri ilkokul 3 ve 4 . sınıf öğrencileri (15900 öğrenci) oluşturmaktadır. Araştırma yapılacak okulların belirlenmesinde seçkisiz olmayan örneklemede amaçsal örneklemin maksimum çeşitlilik örnekleme yöntemi kullanılmıştır. Bu sayede örneklemin kendi içinde olan benzeşik farklı durumlardan oluşturulması sağlanmıştır (Büyüköztürk, 2012). Bu kapsamda araştırmanın örneklemini oluşturan 300 sınıf öğretmeni ve onların 3380 öğrencisinin cinsiyetleri ve (girdikleri) sınıf seviyeleri Tablo 1 ve Tablo 2 ' de gösterilmiştir.

Tablo 1

Sınıf Öğretmenlerinin Cinsiyetleri ve Ders Verdikleri Sınıf Seviyelerinin Dă̆glımı

\begin{tabular}{lccc}
\hline Öğretmen Cinsiyeti & $\mathbf{n}$ & $\mathbf{0}$ & $\mathbf{n}$ \\
\hline Kadın & 207 & 69 & \\
\cline { 1 - 2 } Erkek & 93 & 31 & \multirow{2}{*}{300} \\
\hline Öğretmenin Ders Verdiğ̈i Sınıf Seviyesi & & & \\
\hline 3. sınıf & 154 & 51.3 \\
\hline 4. sınıf & 146 & 48.7 & \\
\hline
\end{tabular}

Tablo 2

Araştırmaya Katılan Öğrencilerin Cinsiyetleri ve Sını Seviyelerinin Dağılımları

\begin{tabular}{|c|c|c|c|}
\hline Öğrenci Cinsiyet & $\mathrm{n}$ & $\%$ & $\mathbf{n}$ \\
\hline K1z & 1703 & 50.4 & \\
\hline Erkek & 1677 & 49.6 & \\
\hline Öğrenci Sınıf Seviyesi & & & 3380 \\
\hline 3. sinif & 1739 & 51.4 & \\
\hline 4. sinif & 1641 & 48.6 & \\
\hline
\end{tabular}

\section{Veri Toplama Araçları}

\section{Sınıf öğretmeni matematik kaygı ölçeği (Ö- MKÖ)}

Çalışmada sınıf öğretmenlerinin matematik kaygılarını ölçmek için, Yıldırım ve Gürbüz (2017) tarafından geliştirilen "Öğretmenlere Yönelik Matematik Kayg1 Ölçeği” (Ö-MKÖ) kullanılmıştır. Kaygı ölçeği, 33 maddeden oluşmakta ve ölçekte 5'li likert tipi dereceleme kullanılmıştır. Ölçekte kullanılan maddeler beş farklı alt faktör altında belirlenmiştir (Matematiğin Doğasından Kaynaklı Kaygı, Öz-Yeterlik Kaygısı, Çevresel Kayg1, Teknoloji/Matematik Kaynaklı Kaygı, Matematiksel İletişim Kaygısı). Ölçeğin doğrulayıcı faktör analizi iyilik indeksleri $x^{2} / \mathrm{sd}=2.71, \mathrm{GFI}=0.91$ SRMR=0.07, RMSEA=0.07, NNFI=0.93, CFI=0.92 ve AGFI=0.90'dir. Analiz sonucu elde edilen ölçeğin ölçüt geçerliliği verileri (.81) ve toplam iç tutarlılık katsayısı Cronbach Alpha 
.91 olarak hesaplanmıştır. Yapılan analizler sonucunda, Öğretmenlere Yönelik Matematik Kaygı Ölçeğinin geçerli ve güvenilir bir ölçek olduğu belirlenmiştir

\section{İlkokul öğrencileri matematik kaygı ölçeği (MKÖ)}

İlkokul Öğrencileri Matematik Kaygı Ölçeği (MKÖ), ilkokul 3 ve 4. sınıf öğrencilerinin matematik kaygı düzeylerini belirlemeye yönelik Mutlu ve Söylemez (2018) tarafından geliştirilmiştir. Yapılan analizle 3 faktörlü bir yapı ve toplam 13 ölçek maddesinden oluşan bir ölçme aracı geliştirilmiştir. Ölçekte kullanılan maddeler üç farklı alt faktör altında olduğu belirlenmiştir. Bunlar; Olumlu Duygular, Olumsuz Tutum, Çekinme ve Endişelenmedir. İlkokul Öğrencileri Matematik Kaygı Ölçeğinin tamamı için Cronbach Alpha güvenirlik katsayısı .75 olarak hesaplanmıştır. Daha sonra doğrulayıcı faktör analizi uygulanmıştır. Analiz sonuçları; ölçeğin faktör yapısının uyumlu olduğunu doğrulamıştır. Elde edilen veriler, geliştirilen matematik kaygı ölçeğinin ilkokul 3 ve 4 . sınıf öğrencilerinin matematik kaygı düzeylerini ölçmekte geçerli ve güvenilir bir araç olduğunu göstermiştir.

\section{Verilerin Analizi}

Araştırmada, 300 sınıf öğretmeni ve 3380 ilkokul 3 ve 4 . sınıf öğrencilerine uygulanan matematik kaygı ölçeklerinin verilerinin analizinde istatistik işlemler için bir istatistik analiz programından yararlanılmıştır. Matematik kaygı ölçeğine verilen yanıtlardan elde edilen puanların parametrik testlere uygunluğu test edilmiştir. Parametrik testlerin uygulanabilmesi için verilerin normal dağılım sergilemesi gerekmektedir (Çokluk, Şekercioğlu ve Büyüköztürk, 2014). Bu şarta uygun olarak dağılımın normalliğini test etmek için; "Tek Örneklem Kolmogorov-Smirnov Normallik Testi" ile analizler yapılmıştır. Verilerin analiz sonucu değerlendirildiğinde sınıf öğretmenlerinin de öğrencilerinin de kendi içlerinde yapılan normallik testleri değerlendirildiğinde sınıf öğretmenlerinin normallik değerinin $(p=.267)$ normal dağılım gösterdiği saptanmıştır. Öğretmenlerin verilerinin homojen dağılım göstermesinden dolayı parametrik testlerin uygulanmasına karar verilmiştir. Analiz sonucu değerlendirildiğinde öğrencilerin normallik değerlerinin ise $(p=.000)$ normal olmadığ1 saptanmıştır. Fakat Büyüköztürk, Çokluk ve Şekercioğlu'na (2012) göre öğrenci örneklem sayısı (1000 sayısından fazla) 3380 olduğundan dolayı parametrik testler uygulanır. Öğretmen ve öğrenciler için bağımsız örnekleme uygun testler uygulanmıştır. Kaygı düzeyi, cinsiyet ve sınıf seviyesi (3. sınıf-4. sınıf) bağımsız örneklem t-testi ile analizler yapılmıştır. İkiden fazla değişken için tek yönlü varyans analizi (One Way ANOVA) ve fark bulunmuşsa Tukey analizi uygulanmıştır. Mesleki yaş-kıdem ve Öğretmen-Öğrenci Kaygi İlişkisini analiz etmek için Pearson Momentler Korelasyon Analizi uygulanmıştır. Analiz sonuçları ve açıklamaları tablolar aracılığıyla bulgular bölümünde verilmiştir.

\section{Araştırmanın Etik İzinleri}

Yapılan bu çalışmada "Yükseköğretim Kurumları Bilimsel Araştırma ve Yayın Etiği Yönergesi" kapsamında uyulması belirtilen tüm kurallara uyulmuştur. Yönergenin ikinci bölümü olan “Bilimsel Araştırma ve Yayın Etiğine Aykırı Eylemler” başlığı altında belirtilen eylemlerden hiçbiri gerçekleştirilmemiştir. Çalışmanın etik kurul izinleri Akdeniz Üniversitesi Rektörlüğü Sosyal ve Beşerî Bilimler Bilimsel Araştırma ve Yayın Etiği Kurulu'ndan 13.09.2018 tarih ve 124 sayılı belge ile alınmıştır. 


\section{Bulgular}

Matematik kaygı ölçeğine verilen yanıtlardan elde edilen puanların parametrik testlere uygunluğu test edilmiştir. Parametrik testlerin uygulanabilmesi için verilerin normal dağılım sergilemesi gerekmektedir (Çokluk ve ark., 2014). Bu şartın sağlanıp sağlanmadığını belirlemek amacıyla verilerin basıklık çarpıklık katsayıları incelenmiştir. Yapılan incelemeler sonucu dağılımların normal dağılım göstermesinden dolayı dağılımlara parametrik testler uygulanmıştır.

\section{Sınıf Öğretmenlerinin Matematik Kaygılarına Yönelik Genel Bulgular}

Araştırmaya katılan sınıf öğretmenlerinin Öğretmenlere Yönelik Matematik Kayg1 Ölçeğine verdikleri yanıtlara ait alt faktör puanlarına ilişkin ortalama ve standart sapma değerleri Tablo 3 'te gösterilmiştir.

Tablo 3

Sınıf Öğretmenlerinin Matematik Kaygı Puanlarına İlişkin Ortalama Değer Analizi

\begin{tabular}{lccc}
\hline Alt Faktörler & n & $\square$ & SS \\
\hline Matematiğin Doğasından Kaynaklı Kaygı & 300 & 1.86 & .55 \\
\hline Öz- Yeterlik Kaygısı & 300 & 2.27 & .64 \\
\hline Çevresel Kayg1 & 300 & 2.28 & .67 \\
\hline Teknoloji/Matematik Kaynaklı Kaygı & 300 & 2.45 & .61 \\
\hline Matematiksel İletişim Kaygısı & 300 & 1.87 & .61 \\
\hline Toplam Kaygı & 300 & 2.14 & .49 \\
\hline
\end{tabular}

Tablo 3 incelendiğinde genel olarak sinıf öğretmenlerinin matematiği öğretmeye yönelik toplam kayg1 puanlarının Öğretmen Kayg1 Ölçeği puan aralıklarına göre düşük olduğu saptanmıştır $(\bar{x}=2.14)$. Matematiğin doğasına yönelik durumları içeren ve matematiğin kendi yapısından kaynaklanan kaygı analiz sonucunda düşük çıkmıştır. En yüksek kaygı puanı ortalaması ise Teknoloji/Matematik Kaynaklı Kaygı alt faktörüne aittir.

\section{Sınıf Öğretmenlerinin Matematik Kaygı Puanlarının Cinsiyet Değişkeni Açısından Değerlendirilmesine İlişkin Bulgular}

Öğretmenlerin Matematik Kayg1 Ölçeği puanlarının cinsiyet değişkenine göre anlamlı bir farklılık gösterip göstermediğini belirlemek amacıyla gerçekleştirilen bağımsız gruplar t-Testi analiz sonuçları Tablo 4 'te gösterilmiştir.

Tablo 4'de görüldüğü üzere Matematiğin Doğasından Kaynaklı Kaygı alt faktöründe erkeklerin lehine anlamlı bir farklılık saptanmıştır. Sınıf öğretmenlerinin Matematiğin Doğasından Kaynaklı Kaygı alt faktörü hariç Öz-Yeterlik Kaygısı, Çevresel Kaygı, Teknoloji/Matematik Kaynaklı Kaygı, Matematiksel İletişim Kaygısı ve toplam kaygıda cinsiyete göre anlamlı bir farklılık tespit edilmemiştir. Erkek sınıf öğretmenleri kadın meslektaşlarına göre daha fazla matematiğin doğasından kaynaklı kaygı yaşamaktadır. 
Tablo 4

Sınıf Öğretmenlerinin Cinsiyetlerinin Matematik Kaygı Ölçeği Alt Faktörlerine Göre t-Testi Analizi

\begin{tabular}{|c|c|c|c|c|c|c|c|}
\hline Alt Faktörler & Cinsiyet & $\mathbf{n}$ & $\square$ & SS & sd & $\mathbf{t}$ & $\mathrm{p}$ \\
\hline \multirow{2}{*}{$\begin{array}{l}\text { Matematiğin } \\
\text { Doğasından } \\
\text { Kaynaklı Kayg1 }\end{array}$} & Kadın & 207 & 1.81 & .55 & \multirow[t]{2}{*}{298} & \multirow[t]{2}{*}{-2.11} & \multirow[t]{2}{*}{.03} \\
\hline & Erkek & 93 & 1.96 & .54 & & & \\
\hline \multirow{2}{*}{ Öz-Yeterlik Kaygisı } & Kadın & 207 & 2.27 & .68 & \multirow[t]{2}{*}{298} & \multirow[t]{2}{*}{-.04} & \multirow[t]{2}{*}{.09} \\
\hline & Erkek & 93 & 2.27 & .55 & & & \\
\hline \multirow{2}{*}{ Çevresel Kayg1 } & Kadın & 207 & 2.31 & .67 & \multirow[t]{2}{*}{298} & \multirow[t]{2}{*}{1.06} & \multirow[t]{2}{*}{.28} \\
\hline & Erkek & 93 & 2.22 & .65 & & & \\
\hline \multirow{2}{*}{$\begin{array}{l}\text { Teknoloji/Matematik } \\
\text { Kaynaklı Kaygı }\end{array}$} & Kadın & 207 & 2.45 & .60 & \multirow[t]{2}{*}{298} & \multirow[t]{2}{*}{-.05} & \multirow[t]{2}{*}{.95} \\
\hline & Erkek & 93 & 2.45 & .62 & & & \\
\hline \multirow{2}{*}{$\begin{array}{c}\text { Matematiksel } \\
\text { İletişim Kaygısı }\end{array}$} & Kadın & 207 & 1.87 & .60 & \multirow[t]{2}{*}{298} & \multirow[t]{2}{*}{.22} & \multirow[t]{2}{*}{.82} \\
\hline & Erkek & 93 & 1.86 & .63 & & & \\
\hline \multirow{2}{*}{ Toplam Kaygı } & Kadın & 207 & 2.14 & .51 & \multirow[t]{2}{*}{298} & \multirow[t]{2}{*}{-.15} & \multirow[t]{2}{*}{.87} \\
\hline & Erkek & 93 & 2.15 & .44 & & & \\
\hline
\end{tabular}

Sınıf Öğretmenlerinin Matematik Kaygı Puanlarının Eğitim Seviyesi Değişkeni Açısından Değerlendirilmesine İlişkin Bulgular

Sınıf öğretmenlerinin matematiği öğretmeye yönelik kaygılarıyla lisans eğitimlerinin anlamlı farklılık gösterip göstermediğini belirlemek amacıyla Tek Yönlü Varyans Analizi (One Way ANOVA) yapılmıştır. Analiz sonucu elde edilen bulgular Tablo 5'de sunulmuştur.

Tablo 5'de görüldüğü üzere sinıf öğretmenlerinin ön lisans-lisans-yüksek lisans; mezuniyet seviyeleri ile Matematiğin Doğasından Kaynaklı Kaygı, Öz-Yeterlik Kayg1sı, Teknoloji/Matematik Kaynaklı Kaygı, Matematiksel İletişim Kaygısı ve Çevresel Kaygı alt faktörler puanlarında ve toplam kaygı puanları arasında anlamlı bir farklılık saptanmamıştır ( $p>$.05). Sınıf öğretmenlerinin ön lisans-lisans-yüksek lisans eğitimi almış olmaları, öğretmenlerin sahip olduğu matematik kaygı puanlarını etkilememektedir. 
Tablo 5

Sını Öğretmenlerinin Lisans Mezuniyet Seviyelerinin Matematik Kaygı Ölçeği Alt Faktörlerine Tek Yönlü Varyans Analizi

\begin{tabular}{|c|c|c|c|c|c|c|c|}
\hline Alt Faktörler & $\begin{array}{c}\text { Sinıf } \\
\text { Öğretmeni } \\
\text { Lisans } \\
\text { Düzeyi } \\
\end{array}$ & $\mathbf{n}$ & $\square$ & ss & $\mathbf{F}$ & sd & $\mathrm{p}$ \\
\hline \multirow{4}{*}{$\begin{array}{l}\text { Matematiğin } \\
\text { Doğasından Kaynaklı } \\
\text { Kaygı }\end{array}$} & Ön lisans & 27 & 1.97 & .57 & 1.51 & 2 & .22 \\
\hline & Lisans & 260 & 1.86 & .55 & & & \\
\hline & $\begin{array}{l}\text { Yüksek } \\
\text { lisans }\end{array}$ & 13 & 1.64 & .54 & & & \\
\hline & Toplam & 300 & 1.86 & .55 & & & \\
\hline \multirow{4}{*}{ Öz- Yeterlik Kaygısı } & Ön lisans & 27 & 2.37 & .56 & .50 & 2 & .60 \\
\hline & Lisans & 260 & 2.26 & .64 & & & \\
\hline & $\begin{array}{l}\text { Yüksek } \\
\text { lisans }\end{array}$ & 13 & 2.17 & .83 & & & \\
\hline & Toplam & 300 & 2.27 & .64 & & & \\
\hline \multirow{4}{*}{ Çevresel Kayg1 } & Ön lisans & 27 & 2.31 & .66 & .98 & 2 & .37 \\
\hline & Lisans & 260 & 2.27 & .67 & & & \\
\hline & $\begin{array}{l}\text { Yüksek } \\
\text { lisans }\end{array}$ & 13 & 2.53 & .69 & & & \\
\hline & Toplam & 300 & 2.28 & .67 & & & \\
\hline \multirow{4}{*}{$\begin{array}{l}\text { Teknoloji/Matematik } \\
\text { Kaynaklı Kaygı }\end{array}$} & Ön lisans & 27 & 2.62 & .74 & 2.01 & 2 & .13 \\
\hline & Lisans & 260 & 2.44 & .60 & & & \\
\hline & $\begin{array}{l}\text { Yüksek } \\
\text { lisans }\end{array}$ & 13 & 2.23 & .44 & & & \\
\hline & Toplam & 300 & 2.45 & .61 & & & \\
\hline \multirow{4}{*}{$\begin{array}{l}\text { Matematiksel İletişim } \\
\text { Kaygısı }\end{array}$} & Ön lisans & 27 & 1.96 & .72 & .32 & 2 & .72 \\
\hline & Lisans & 260 & 1.86 & .60 & & & \\
\hline & $\begin{array}{l}\text { Yüksek } \\
\text { lisans }\end{array}$ & 13 & 1.87 & .53 & & & \\
\hline & Toplam & 300 & 1.87 & .61 & & & \\
\hline \multirow{4}{*}{ Toplam Kayg1 } & Ön lisans & 27 & 2.25 & .46 & .68 & 2 & .50 \\
\hline & Lisans & 260 & 2.14 & .49 & & & \\
\hline & $\begin{array}{l}\text { Yüksek } \\
\text { lisans }\end{array}$ & 13 & 2.09 & .50 & & & \\
\hline & Toplam & & 2.14 & .49 & & & \\
\hline
\end{tabular}

Sınıf Öğretmenlerinin Matematik Kaygı Puanlarının Mezun Olunan Alan Değişkeni Açısından Değerlendirilmesine İlişkin Bulgular

Sınıf öğretmenlerinin matematik kaygı puanlarıyla lisans alanından mezun olmalarına göre anlamlı farklılık gösterip göstermediğini belirlemek amacıyla Tek Yönlü Varyans Analizi (One Way ANOVA) testi yapılmıştır. Analiz sonucu elde edilen bulgular Tablo 6'da sunulmuştur. 
Tablo 6

Sını Öğretmenlerinin Üniversiteden Mezun Olunan Alan ile Matematik Kaygı Ölçeğgi Alt Faktörlerine Göre Tek Yönlü Varyans Analizi

\begin{tabular}{|c|c|c|c|c|c|c|c|}
\hline Alt Faktörler & $\begin{array}{l}\text { Lisans Mezuniyet } \\
\text { Alanı }\end{array}$ & $\mathbf{n}$ & $\square$ & SS & $\mathbf{F}$ & sd & $\mathbf{p}$ \\
\hline \multirow{4}{*}{$\begin{array}{l}\text { Matematiğin } \\
\text { Doğasından Kaynaklı } \\
\text { Kayg1 }\end{array}$} & Sınıf Öğretmenliği & 192 & 1.83 & .52 & \multirow[t]{4}{*}{2.67} & \multirow[t]{4}{*}{2} & \multirow[t]{4}{*}{.71} \\
\hline & Diğer Öğretmenlik & 36 & 2.06 & .60 & & & \\
\hline & Alan dişı & 72 & 1.82 & .60 & & & \\
\hline & Toplam & 300 & 1.86 & .55 & & & \\
\hline \multirow{4}{*}{ Öz-Yeterlik Kaygısı } & Sınıf Öğretmenliği & 192 & 2.22 & .60 & \multirow[t]{4}{*}{4.96} & \multirow[t]{4}{*}{2} & \multirow[t]{4}{*}{.008} \\
\hline & Diğgr Öğretmenlik & 36 & 2.58 & .64 & & & \\
\hline & Alan dişı & 72 & 2.22 & .71 & & & \\
\hline & Toplam & 300 & 2.27 & .64 & & & \\
\hline \multirow{4}{*}{ Çevresel Kayg1 } & Sınıf Öğretmenliği & 192 & 2.27 & .62 & \multirow[t]{4}{*}{.74} & \multirow[t]{4}{*}{2} & \multirow[t]{4}{*}{.47} \\
\hline & Diğer Öğretmenlik & 36 & 2.41 & .68 & & & \\
\hline & Alan dişı & 72 & 2.27 & .77 & & & \\
\hline & Toplam & 300 & 2.28 & .67 & & & \\
\hline \multirow{4}{*}{$\begin{array}{l}\text { Teknoloji/Matematik } \\
\text { Kaynaklı Kayg1 }\end{array}$} & Sınıf Öğretmenliği & 192 & 2.40 & .56 & \multirow[t]{4}{*}{2.03} & \multirow[t]{4}{*}{2} & \multirow[t]{4}{*}{.13} \\
\hline & Diğer Öğretmenlik & 36 & 2.58 & .71 & & & \\
\hline & Alan dişı & 72 & 2.52 & .66 & & & \\
\hline & Toplam & 300 & 2.45 & .61 & & & \\
\hline \multirow{4}{*}{$\begin{array}{l}\text { Matematiksel İletişim } \\
\text { Kaygisı }\end{array}$} & Sınıf Öğretmenliği & 192 & 1.84 & .57 & \multirow[t]{4}{*}{1.95} & \multirow[t]{4}{*}{2} & \multirow[t]{4}{*}{.14} \\
\hline & Diğer Öğretmenlik & 36 & 2.06 & .67 & & & \\
\hline & Alan dişı & 72 & 1.84 & .66 & & & \\
\hline & Toplam & 300 & 1.87 & .61 & & & \\
\hline \multirow{4}{*}{ Toplam Kayg1 } & Sınıf Öğretmenliği & 192 & 2.11 & .44 & \multirow[t]{4}{*}{3.23} & \multirow[t]{4}{*}{2} & \multirow[t]{4}{*}{.04} \\
\hline & Diğer Öğretmenlik & 36 & 2.34 & .51 & & & \\
\hline & Alan dişı & 72 & 2.13 & .57 & & & \\
\hline & Toplam & 300 & 2.14 & .49 & & & \\
\hline
\end{tabular}

Tablo 6'da görüldüğü gibi Öz-Yeterlik Kaygısı alt faktörlerinde katılımcıların mezun oldukları alana göre anlamlı bir farklılık saptanmıştır $(\mathrm{F}=4.96, \mathrm{p}<.05, \mathrm{p}=.008)$. Söz konusu farklılı̆̆ın hangi gruplar arasında olduğunu belirlemek amacıyla veriler, Post Hoc Tukey testi ile analiz edilmiştir. Bu farklılık sınıf öğretmenliği mezunları ile diğer öğretmenlik bölümü mezunları arasında olup diğer öğretmenlik bölümü mezunlarının kaygı puanı yüksektir. Toplam Kaygı puanlarında, sınıf öğretmenlerinin mezun oldukları alana göre anlamlı bir farklılık saptanmıştır $(\mathrm{F}=3.23, \mathrm{p}<.05, \mathrm{p}=.04)$. $\mathrm{Bu}$ farklılı̆̆ın hangi gruplar arasında olduğu belirlemek için Post Hoc Tukey testi yapılmıştır. Sonucunda bu farklılığın sınıf öğretmenliği mezunları ile diğer öğretmenlik mezunları arasında olduğu bulunmuştur. Sonuç, sınıf öğretmenliği mezunu olan öğretmenlerin lehinedir, yani diğer öğretmenlik mezunları sinıf öğretmenliği okuyan öğretmenlerden daha kaygllıdır. Matematiğin Doğasından Kaynaklı Kaygı, Çevresel Kayg1, Teknoloji/Matematik Kaynaklı Kayg1, Matematiksel İletişim Kaygısı alt faktörlerine göre matematik öğretmen kaygısında sınıf öğretmenlerinin üniversiteden mezun olunan alana göre anlamlı bir fark saptanmamiştır ( $\mathrm{p}>$.05). 


\section{Sınıf Öğretmenlerinin Matematik Kaygı Puanlarıyla Kıdemleri Arasındaki İlişkiye Göre Bulguları}

Sınıf öğretmenlerinin matematik öğretimine ilişkin kaygı puanları ile öğretmenlerin kıdemleri arasındaki ilişkiyi anlamak için yapılan Pearson Momentler Çarpımı Korelasyon Analizi Tablo 7'de gösterilmiştir.

Tablo 7

Sını Öğretmenlerinin Matematik Kaygısıyla Kıdemleri Arasındaki Korelasyon Analizi

\begin{tabular}{ll}
\hline Alt Faktörler & Kıdem \\
\hline Matematiğin Doğasından Kaynaklı Kayg1 & $.22^{* *}$ \\
\hline Öz Yeterlik Kaygisı & $.19^{* *}$ \\
\hline Çevresel Kayg1 & -.00 \\
\hline Teknoloji/Matematik Kaynaklı Kayg1 & $.14^{* *}$ \\
\hline Matematiksel İletişim Kaygısı & $.15^{* *}$ \\
\hline Toplam Kayg1 & $.17^{* *}$ \\
\hline$*$ Korelasyonel anlamlılık 0.05 seviye. &
\end{tabular}

Tablo 7'de görüldüğü üzere sınıf öğretmenlerinin, matematik kaygı puanları ile kıdemleri arasında; Matematiğin Doğasından Kaynaklı Kayg1 $\left(r=.22^{* *}\right)$, Öz-Yeterlik Kaygisı $\left(\mathrm{r}=.19^{* *}\right)$, Teknoloji/Matematik Kaynaklı Kayg1 $\left(\mathrm{r}=.14^{* *}\right)$, Matematiksel İletişim Kaygısı $\left(\mathrm{r}=.15^{* *}\right)$ ve Toplam Kaygı $\left(\mathrm{r}=.17^{* *}\right)$ faktörlerinde pozitif yönde anlamlı bir ilişki bulunmuştur Analizlerin dört alt faktör için matematik kaygısı ile kıdem arasında düşük düzeyde, pozitif yönde, anlamlı bir ilişki taşıdığı saptanmıştır. Yalnızca Çevresel Kaygı ( $\mathrm{r}=.01,-.00)$ faktöründe öğretmenlerin kıdemleri arasında anlamı bir ilişki saptanmamıştır.

\section{İlkokul Öğrencilerinin Kaygı Puanlarının Değerlendirilmesine İlişkin Bulgular}

Araştırmada ilkokul öğrencilerinin matematik kaygı puanlarını belirlemek amacıyla alt faktörlerin ortalama değerlerine bakılmıştır. Analiz sonuçları Tablo 8'de sunulmuştur.

Tablo 8

İlkokul Öğrencilerinin Matematik Kaygı Puanlarına İlişkin Ortalama Değer Analizi

\begin{tabular}{lccc}
\hline Alt Faktörler & $\mathbf{n}$ & $\square$ & SS \\
\hline Olumlu Duygular & 3380 & 2.70 & .40 \\
\hline Olumsuz Tutum & 3380 & 1.70 & .49 \\
\hline Çekinme-Endişelenme & 3380 & 1.36 & .48 \\
\hline
\end{tabular}

Tablo 8'de görüldüğü üzere öğrenci matematik kayg1 ölçeği alt faktör ortalamaları 1.36 ile 2.70 arasında değişmektedir. Çekinme-Endişelenme alt faktörü $(\square=1.36, \mathrm{SS}=.48)$ ölçek derecelendirme puanlarına düşük seviyededir. Olumsuz Tutum kaygısı ( $\square=1.70, S S=.49)$ ölçek derecelendirme puanlarına göre orta seviyededir. Olumlu Duygular faktörü ise $(\square=2.70, S S=.40)$ ölçek değerlendirme puanlarına göre yüksek seviyededir. En yüksek değerli ortalama ise Olumlu Duygular alt faktörüne aittir. 
İlkokul Öğrencilerinin Matematik Kaygı Puanlarının Cinsiyet Değişkeni Açısından Değerlendirilmesine İlişkin Bulgular

İlkokul öğrencilerinin matematik konusunda kaygı puanlarının cinsiyete göre farklılık gösterip göstermediğini belirlemek için Bağımsız Gruplar t-Testi yapılmıştır. Analiz sonucundan elde edilen bulgular Tablo 9' da gösterilmiştir.

Tablo 9

İlkokul Öğrencilerinin Cinsiyetlerinin Matematik Kaygı Ölçeği Alt Faktörlerine Göre t-Testi Analizi

\begin{tabular}{|c|c|c|c|c|c|c|c|}
\hline Alt Faktörler & Cinsiyet & $\mathbf{N}$ & $\square$ & SS & sd & $\mathbf{t}$ & $\mathbf{p}$ \\
\hline \multirow{2}{*}{ Olumlu Duygular } & $\mathrm{K}_{1 \mathrm{Z}}$ & 1703 & 2.68 & .41 & \multirow[t]{2}{*}{3378} & \multirow[t]{2}{*}{-1.61} & \multirow[t]{2}{*}{.10} \\
\hline & Erkek & 1677 & 2.71 & .40 & & & \\
\hline \multirow{2}{*}{ Olumsuz Tutum } & $\mathrm{K}_{1 \mathrm{Z}}$ & 1703 & 1.78 & .49 & \multirow[t]{2}{*}{3378} & \multirow[t]{2}{*}{1.72} & \multirow[t]{2}{*}{.08} \\
\hline & Erkek & 1677 & 1.68 & .48 & & & \\
\hline \multirow{2}{*}{ Çekinme-Endişelenme } & $\mathrm{K}_{1 \mathrm{Z}}$ & 1703 & 1.38 & .48 & \multirow[t]{2}{*}{3378} & \multirow[t]{2}{*}{2.10} & \multirow[t]{2}{*}{.03} \\
\hline & Erkek & 1677 & 1.35 & .46 & & & \\
\hline
\end{tabular}

Tablo 9'da görüldüğü üzere ilkokul öğrencilerinin Çekinme-Endişelenme alt faktöründe t-testi sonuçlarına göre kızların lehine anlamlı bir farklılık saptanmıştır $\left(\mathrm{t}_{(3378)}=2.10 ; \mathrm{p}=.03, \mathrm{p}<.05\right)$. Bu sonuç, $\mathrm{k} 1 \mathrm{z}$ öğrencilerin erkek öğrencilere göre daha fazla Çekinme-Endişelenme kaygısı yaşadığını göstermektedir. Olumlu Duygular ve Olumsuz Tutum alt faktörlerinde cinsiyete göre anlamlı farklılık tespit edilmemiştir (p>.05). Öğrencilerin matematiğe göre Olumlu Duyguları ve Olumsuz Tutum puanları, cinsiyet açısından istatistiksel olarak anlamlı bir farklılık oluşturmamaktadır.

\section{Sınıf Öğretmenlerinin Matematik Kaygı Puanları ile Öğrencilerinin Matematik Kaygı Puanlarının İlişkisinin Değerlendirmesinin Bulguları}

Sınıf öğretmenleri ve ders verdikleri öğrencilerin matematik kaygılarını anlamlı bir ilişkisinin olup olmadığının incelenmesi amacıyla yapilan Pearson Momentler Çarpımı Korelasyon Analizi uygulanmıştır. Araştırma bulguları Tablo 10'da sunulmuştur.

Tablo 10'da görüldüğü gibi sınıf öğretmenlerinin Öz-Yeterlik Kayg1sı ile öğrencilerinin Olumsuz Tutum alt faktörü arasında korelasyonel anlamlı bir ilişki vardır $\left(r=.12^{*}\right)$. Buna göre öğretmenlerin sahip olduğu Öz-Yeterlik Kaygısının, öğrencilerinde Olumsuz Tutuma neden olduğu söylenebilir. Sınıf öğretmenlerinin Matematiksel İletişim Kaygısı alt faktörüyle, öğrencilerinin Çekinme-Endişelenme Kaygısı arasında anlamlı bir ilişki mevcuttur $\left(\mathrm{r}=.13^{*}\right)$. Buna göre sınıf öğretmenlerinin matematik derslerine yönelik sahip oldukları genel iletişim kaygılarının öğrencilerinde çekinme ve endişelenmeye neden olduğu söylenebilir. Sınıf öğretmenlerinin Toplam Kaygı puanları ile öğrencilerinin Çekinme-Endişelenme alt faktörü arasında anlamlı bir ilişki saptanmıştır $\left(r=.12^{*}\right)$. Bu duruma göre ise sınıf öğretmenlerinin sahip olduğu genel matematik kaygılarının sınıftaki öğrencilerinde çekinme ve endişelenmeye ve devamında öğrencilerin matematik dersini sevmemelerine neden olduğu söylenebilir. 
Tablo 10

Sınıf Öğretmenlerinin Matematik Kaygısı ile Sınıfında Ders Verdikleri Öğrencilerin Matematik Kaygısı Arasindaki Korelasyon Analizi

\begin{tabular}{|c|c|c|c|c|c|c|c|c|c|}
\hline Alt Faktörler & 1. & 2. & 3. & 4. & 5. & 6. & 7. & 8. & 9. \\
\hline $\begin{array}{l}\text { 1.Matematiğin } \\
\text { Doğasından } \\
\text { Kaynaklı Kayg1 }\end{array}$ & 1 & $.61^{* *}$ & $.42^{* *}$ & $.39 * *$ & $.67^{* *}$ & $.77^{* *}$ & -.02 & -.00 & .08 \\
\hline $\begin{array}{l}\text { 2.Öz-Yeterlik } \\
\text { Kaygısı }\end{array}$ & & 1 & $.55^{* *}$ & $.49^{* *}$ & $.67^{* *}$ & $.84^{* *}$ & -.01 & $.12^{* *}$ & .10 \\
\hline 3.Çevresel Kayg1 & & & 1 & $.46^{* *}$ & $.56^{* *}$ & $.77^{* *}$ & .02 & .09 & .06 \\
\hline $\begin{array}{l}\text { 4.Teknoloji/ } \\
\text { Matematik } \\
\text { Kaynaklı Kaygı } \\
\end{array}$ & & & & 1 & $.46^{* *}$ & $.71^{* *}$ & -.10 & .10 & .11 \\
\hline $\begin{array}{l}\text { 5.Matematiksel } \\
\text { İletişim Kaygisı }\end{array}$ & & & & & 1 & $.85^{* *}$ & -.09 & .10 & $.13^{* *}$ \\
\hline 6.Toplam Kayg1 & & & & & & 1 & -.05 & .10 & $.12^{* *}$ \\
\hline $\begin{array}{l}\text { 7.Olumlu } \\
\text { Duygular }\end{array}$ & & & & & & & 1 & $-.49^{* *}$ & $-.44^{* \varkappa}$ \\
\hline $\begin{array}{l}\text { 8.Olumsuz } \\
\text { Tutum }\end{array}$ & & & & & & & & 1 & .54 \\
\hline $\begin{array}{l}\text { 9.Çekinme- } \\
\text { Endişelenme }\end{array}$ & & & & & & & & & 1 \\
\hline
\end{tabular}

Tartışma, Sonuç ve Öneriler

Korelasyon katsayısının anlamlı bir şekilde farklılık gösterip göstermediği büyük ölçüde puanların toplandığı denek sayısına bağlıdır. Örneğin 5 kişiden oluşan ve hesaplanan $\mathrm{r}=70 \mathrm{a}=.05$ 'te anlamlı değildir. Buna karşılık 100 kişilik bir örnekten hesaplanan $\mathrm{r}=20 \mathrm{a}=.05^{\prime}$ de anlamlidir.

Sınıf öğretmenlerinin matematik kaygılarına yönelik araştırma sorusuna ilişkin bulgular doğrultusunda sınıf öğretmenlerinin Toplam Kaygı puanlarının ortalaması 2.14'tür. Çalışmanın alt faktörleri incelendiğinde yalnızca Matematiğin Doğasından Kaynaklı Kayg1 (1.86) ve Matematiksel İletişim Kaygısının (1.87) ortalamanın altında olduğu görülmektedir. Bunun nedeni ise sinıf öğretmenlerinin derslerindeki matematik öğretimlerinin faydalı olduğunu düşünmeleri ve matematiğin kendine has alışılmış bir iletişim dili olduğunu düşünmeleri olabilir. Öz-Yeterlik Kaygısı, Çevresel Kaygı ve Teknoloji/Matematik Kaynaklı Kaygılarının yüksek çıkmasının sebepleri olarak öğretmenlerin matematik alan bilgisinin yeterli olmadığ1 ve örneklem oluşturan sınıf öğretmenlerinin yaşlarının genel olarak büyük olmasının teknolojik cihazları kullanma sevileriyle ters bir korelasyon gösterdiği söylenebilir. McAnallen 
(2010) ve Yıldırım'da (2013) araştırmalarında bu problem sonucuna benzer olarak öğretmenlerin matematik kaygı puanlarının düşük olduğunu tespit etmiştir. Frank'in (1990) yaptığı araştırmaya göre matematiğe karşı olumsuz tutuma sahip kişilerin, daha önceki yıllarda matematik öğretmenleriyle aralarında olumsuz tecrübeler yaşadığ1 ve bunun ilerleyen dönemlerde matematik kaygısı olarak devam ettiği belirlenmiştir. Alkan (2011) öğretmenlerin öğrencilerinde derslerle ilgili duyuşsal özelliklerin (sevme, nefret etme, kaygı, tutum) oluşmasında büyük bir etkiye sahip olduklarını belirlemiştir.

Sınıf öğretmenlerinin kaygı puanlarının yalnızca bir faktör dışında cinsiyete göre anlamlı farklılık göstermediği görülmüştür. Bu bulguyu destekler nitelikte Brush (1978), Dreger ve Aiken (1957), Fee-Fulkerson (1983), Freeman (1982), Ling (1982) ve Olson (1985) çalışmalarında öğretmenlerin kaygı düzeylerinde cinsiyete göre istatistiki anlamda bir fark bulmamışlardır. Üldaş (2005), yaptığı araştırmada öğretmenlerin, Peker (2009b) ise öğretmen adaylarının cinsiyet değişkenine göre matematik kaygısında anlamlı bir fark bulmamıştır. Sınıf öğretmenlerinin yalnızca Matematiğin Doğasından Kaynaklı Kayg1 alt faktöründe cinsiyete göre anlamlı farklılık tespit edilmiştir ve erkek öğretmenlerin, kadın meslektaşlarına göre daha fazla kaygı yaşadığı bulunmuştur. Linn ve Kessel (1996) de erkek öğretmenlerin kadın öğretmenlerden daha fazla matematik kaygısı taşıdığını hesaplamıştır. Araştırma sonucunun aksine kadınların erkeklerden daha fazla matematik kaygısını yaşadığını belirten araştırmalar da vardır (Alexander ve Martray, 1989; Eldemir, 2006).

Sınıf öğretmenlerinin matematik kaygı puanlarının okutulan sınıf seviyesi değişkeni açısından değerlendirilmesine ilişkin analiz sonuçlarına göre, Toplam Kaygı puanı ve Çevresel Kaygı puanı 4. sınıf öğretmenlerinin 3. sınıf öğretmenlerine göre anlamlı şekilde farklılaşmakta olup, 4. sınıf öğretmenlerinin kaygı puanları daha yüksektir. Bu sonuca göre, 4. sınıf öğretmenleri, 3. sınıf okutan meslektaşlarına göre daha fazla Toplam Kaygı ve Çevresel Kaygı yaşamaktadır denilebilir. 4. sınıf matematik konularının 3. Sınıfa göre iki kat yakın olması, ilerleyen soyut kavramlar ve öğrencilerin derslere olan ilgililerinin azalması öğretmenlerde kaygıya sebep olduğu söylenebilir. Bu durum öğrencilerde oluşan ve artan kaygının sonraki yıllarda da devam etmesine neden olabilir. Gürbüz ve Yıldırım (2016), 1, 2 ve 3. sınıfları okutan öğretmenlerin matematik kaygısında bir fark bulmamış fakat 4. sınıf öğretmenlerinde manidar şekilde daha fazla kaygı bulmuştur. Diğer yandan Başpınar (2015), araştırmasında matematik öğretimi konusunda sınıf öğretmeni adaylarının kaygı düzeylerinin alt faktörlerin tamamında sınıf seviyesine göre anlamlı bir farklılık olmadığı sonucuna varmıştır.

Sınıf öğretmenlerinin matematik kaygı puanlarının eğitim seviyesi değişkeni açısından değerlendirilmesine ilişkin analiz sonuçlarına göre sınıf öğretmenlerinin ön lisans/lisans/yüksek lisans seviyelerine göre matematik kayg1 ölçeği alt faktörleri ve Toplam Kaygı puanları arasında anlamlı bir farklılık saptanmamıştır. Yıldırım (2013), sınıf öğretmenlerinin matematik kaygısını araştırdığı çalışmasında yüksek lisans yapan sınıf öğretmenlerinin matematik kaygı puanlarının, yüksek lisans yapmayan sınıf öğretmenlerinin matematik kaygısı puanlarından anlamlı şekilde daha düşük olduğu sonucuna ulaşmiştır.

Sınıf öğretmenleri matematik kaygı puanları mezun olunan alan değişkeni açısından değerlendirildiğinde Toplam Kaygı ve Öz-Yeterlik Kaygısı faktöründe 
anlamlı farklılık saptanmıştır. Diğer öğretmenlik bölümü mezunlarının sınıf öğretmenlerinden daha fazla kaygıya sahip olduğu bulunmuştur. Sınıf öğretmenliği programı dışındaki öğretmenlik programlarından mezunlarının ilkokul seviyesinde öğretim verme konusunda kendilerini yeterli görmedikleri ve bunun kaygıya neden olduğunu söylenebilir. Gündüz'ün (2005) ve Yıldırım'ın (2013) araştırmalarında da diğer bölümlerden mezun öğretmenlerin sınıf öğretmenliği mezunu olan sınıf öğretmenlerinden daha yüksek kaygıya sahip olduğu sonucuna ulaşılmıştır. Bu durumun nedeni olarak sınıf öğretmeni yetiştirme programlarının alan eğitimi dersleri alması ve sınıf öğretmenlerinin üniversite eğitimi boyunca matematik öğretimi dersi sayesinde matematik kaygısını en aza indirgedikleri sayılabilir. Kilmen ve Demirtaşlı (2009) çalışmalarında kaygı ile mezun olunan bölüm değişkenine göre anlamlı bir fark bulmamıştır. Ertürk ve Keçecioğlu (2012) ise sınıf öğretmenliği mezunlarının, diğer fakülte mezunu olan sınıf öğretmenlerinden daha kaygılı olduğu sonucuna ulaşmıştır.

Sınıf öğretmenlerinin matematik kaygı puanlarıyla kıdemleri arasındaki ilişki değerlendirildiğinde sadece bir alt faktör hariç matematik kaygısı ile kıdem arasında anlamlı ve pozitif yönde ilişki olduğu görülmüştür. Öğretmenlerin kıdemlerinin artmasıyla matematik kaygılarının da düşük düzeyde arttığ1 söylenebilir. Yapılan bazı araştırmalarda da kıdemin artmasıyla kaygının da arttı̆̆ı bulgusuna ulaşılmıştır. (Betz, 1978; Richardson ve Suinn, 1972). Fakat Üldaş'a (2005) göre öğretmenlerin matematik kaygı puanlarıyla yaşları/kıdemleri arasında ters yönde ve anlamlı düzeyde ilişki saptanmıştır, yani yaş/kıdem arttıkça matematik kaygı puanları azalmaktadır. Yine bu araştırmayı destekler nitelikte sadece kaygı puanları ile yaş/kıdem değişkenini inceleyen Girgin (1995) ve Yıldırım' a (2013) göre öğretmenlerin yaşlarının artmasıyla kaygılarının azaldığı sonucu bulunmuştur. Öğretmenlerin yaşlarının ilerlemesi, mesleki tecrübe kazanmaları, öğrettikleri tüm alana daha fazla hâkim olmaları, belli bir olgunluğa ulaşmalarını sağlamış bu da matematik kaygılarının daha da azalmasını desteklemiş olabilir. Öte yandan yaşı/kıdemi daha az olan öğretmenlerde daha fazla matematik kaygısının olmasının sebepleri; deneyimsizlik, mesleği ve alanı henüz yeterince tanımama sayılabilir. Diğer yandan Wiggins (1984) ise matematik kaygısı ile öğretmenlikte geçen hizmet süresi arasında anlamlı bir ilişki bulmamıştır.

Gilroy (2002) ile Miller ve Mitchell'e (1994) göre öğrencilerin olumsuz tutum geliştirmelerinin sebepleri arasında günlük hayatla matematik dersi arasında bağlantı kuramamaları ve matematik dersinde öğrendiklerini günlük hayatta çözüm yolu olarak kullanmamaları belirtilmektedir. Çekinme-Endişelenme alt faktörü, kaygı puan ortalamasında düşük seviyededir. Öğrencilerin matematiğe karşı olan Çekinme Endişelenme düzeylerinin düşük olması, öğrencilerin matematik dersini öğrenmelerine engel olabilen endişelenme duygu durumunun az olduğunu göstermektedir (Bindak, 2005).

İlkokul öğrencilerinin Olumlu Duygular alt faktörü ve Olumsuz Tutum alt faktörlerinde cinsiyete göre anlamlı bir farklılık tespit edilmemiştir. Buna göre öğrencilerdeki matematik kaygısının cinsiyet değişkenine göre bir fark oluşturmadığı söylenebilir. Yapılan bazı araştırmalarda bu sonucu destekler nitelikte cinsiyet değişkeni matematik kaygısında anlamlı bir fark oluşturmamıştır (Cooper ve Robinson, 1991; Dede ve Dursun, 2008; Kacar ve Sarıçam, 2015; Yüksel-Şahin, 2008). 
Çekinme-Endişelenme alt faktöründe ise t-Testi sonuçlarına göre erkeklerin lehine anlamlı bir farklılık belirlenmiştir. Bu sonuç, kız öğrencilerin erkek arkadaşlarına göre daha fazla Çekinme-Endişelenme kaygısı yaşadığını ifade etmektedir. Fakat bazı araştırma sonuçlarında bu sonucun tersi çıkmıştır (Aydın ve ark., 2009; Baloğlu, 2004; Yüksel-Şahin, 2008). Araştırmalarda cinsiyetin en çok araştırılan değişken olmasının yanı sıra sonuçların farklı çıkmasının nedenleri arasında matematik kaygısının bilişsel bir süreçte gerçekleşmesi ve zihinde farklı mekanizmalarla ve çevresel etkilerle tetiklenmesi gösterilmektedir. Kaygının ise bilişsel ve duyuşsal hatta zaman zaman davranışsal etki ve belirtilere neden olduğu için cinsiyetten etkilenmemesi olağan karşılanmaktadır (Baloğlu, 2001).

Araştırma bulgularından elde edilen sonuçlara göre sınıf öğretmenlerinin ÖzYeterlik Kaygısı ile öğrencilerinin Olumsuz Tutum alt faktörü arasında anlamlı bir ilişki vardır. Ayrıca sınıf öğretmenlerinin Matematiksel İletişim Kaygısı alt faktörüyle öğrencilerinin Çekinme-Endişelenme Kaygısı arasında anlamlı ilişki mevcuttur. Bunlara ek olarak sınıf öğretmenlerinin Toplam Kaygı puanları ile öğrencilerinin Çekinme-Endişelenme alt faktörü arasında anlamlı bir ilişki saptanmıştır. Matematik kaygısı üzerine yapılan çalışmalarda matematik kaygısı taşıyan insanlarla geçmişte matematik öğretmenleri arasında bir bağlantının olduğu tespit edilmiştir (Perry, 2004). Alkan (2011) öğretmenlerin, öğrencilerinin duyuşsal özellikleri üzerinde özellikle de kaygı oluşmasında büyük bir rolü olduğunu tespit etmişlerdir. Jackson ve Leffingwell (1999) yaptıkları araştırmada sınıf öğretmenlerinin öğrenciler üzerinde oluşturdukları olumsuz izlenimlerin öğrenciler tarafından unutulmadığını ve öğrencileri uzun süre etkilediğine dair yaptıkları bilimsel araştırmada bu izlenimlerin 12 yıl ve daha fazla süre hatırlandığını belirlemişlerdir. Yapılan bir diğer araştırmada, Uusimaki ve Nason (2004) sınıf öğretmeni adaylarının sahip olduğu orta seviyedeki kaygının geçmişte ilkokulda öğretmenleriyle yaşadıkları olumsuz tecrübelerden kaynaklandığı yorumuna ulaşılmıştır. Bu çalışmalardan ulaşılan sonuçlar, bu araştırmadan çıkan sonuçlarla benzerlik göstermektedir.

$\mathrm{Bu}$ araştırma 3 ve 4 . sınıf öğrencileri ile yapılmıştır. Alanyazında 3 ve 4 . sınıf öğrencilerinin matematik kaygı düzeylerini araştıran çalışmalar, ortaokul, lise ve üniversite öğrencileriyle yapılan araştırma sayılarına göre yeterli olmadığ1 görülmüştür. Öğrencilerin en temel derslerinden biri matematiktir. İlköğretimin ilk kademesinde başlayan matematik kaygısı eğer önlenemezse, ilerideki öğrenim yıllarında bu kaygılar artarak devam edeceği kaçınılmazdır. Bu yüzden matematik kaygısı konusunda ilkokul öğrencileriyle ilgili daha fazla nicel ve nitel araştırmalar yapılabilir. Öğretmenlerle kaygıyı önleyici eğitimsel çalışmalar yapılabilir.

\section{Kaynakça}

Akgül, S. (2008). İlköğretim ikinci kademe 7. ve 8. sinıföğrencilerinin matematik kaygılan ile algıladıkları öğretmen sosyal desteğinin cinsiyete göre matematik başarıların yordama gücü (Yüksek Lisans Tezi, Yıldız Teknik Üniversitesi, Sosyal Bilimler Enstitüsü, İstanbul), https:// tez.yok.gov.tr/ adresinden edinilmiştir.

Alexander, L., and Martray, C. (1989). The development of an abbreviated version of the mathematics anxiety rating scale. Measurement and evaluation in counseling and development, 22(3), 143-150. https:// doi.org/10.1080/07481756.1989.12022923

Alkan, V. (2011). Etkili matematik öğretiminin gerçekleştirilmesindeki engellerden 
biri: Kayg1 ve nedenleri. Pamukkale Üniversitesi Eğitim Fakültesi Dergisi, 29(29), 89-107.

Ashcraft, M. H. (2002). Math anxiety: Personal, educational, and cognitive consequences. Current Directions in Psychological Science, 11(5), 181-185. https:/ / doi.org/10.1111/1467-8721.00196

Ashcraft, M. H., and Ridley, K. S. (2005). Math anxiety and its cognitive consequences: Atutorial review. In J. I. D. Campbell (Ed.), Handbook of Mathematical Cognition, 315-330. New York: Psychology Press.

Aydın, E., Delice, A., Dilmaç, B. ve Ertekin, E. (2009). İlköğretim matematik öğretmen adayların matematik kaygı düzeylerine cinsiyet, sınıf ve kurum değişkenlerinin etkileri. İlköğretim Online, 8(1), 231-242.

Baloğlu, M. (1999). A comparison of mathematics anxiety and statistics anxiety in relation to general anxiety. Eric Document Reproduction Service No. 436703.

Baloğlu, M. (2001). Matematik korkusunu yenmek. Kuram ve Uygulamada Ĕ̆itim Bilimleri Dergisi, 1(1), 59-76.

Baloğlu, M. (2004). Üniversite öğrencilerinin matematik kaygı düzeyleri açısından karşılaştırılması. XIII. Ulusal Eğitim Bilimleri Kurultayı. 6-9 Temmuz, İnönü Üniversitesi, Malatya.

Başpınar, K. (2015). Sını öğretmeni adaylarının matematiksel inançları ve matematik öğretme kaygıları üzerine bir araştırma, (Yüksek Lisans Tezi, Afyon Kocatepe Üniversitesi, Sosyal Bilimler Enstitüsü, Afyon), https://tez.yok.gov.tr/ adresinden edinilmiştir.

Beilock, S. L., Gunderson, E. A., Ramirez, G., and Levine, S. C. (2010). Female teachers' math anxiety affects girls' math achievement. Proceedings of the National Academy of Sciences, 107(5), 1860-1863.

Bekdemir, M. (2007). İlköğretim matematik öğretmen adaylarındaki matematik kaygısının nedenleri ve azaltılması için öneriler (Erzincan Eğitim Fakültesi Örneği). Erzincan Ĕ̆itim Fakültesi Dergisi, 9(2), 131-144.

Bekdemir, M., Işık, A. ve Çıkılı, Y. (2004). Matematik kaygısını oluşturan ve artıran öğretmen davranışları ve çözüm yolları. Eurasian Journal of Educational Research (EJER), 16, 88-94.

Betz, N. E. (1978). Prevalence, distribution, and correlates of math anxiety in college students. Journal of Counselling Psychology, 25(5), 441-448. https:/ / doi.org/10.1037/t02344-000

Bindak, R. (2005). İlköğretim öğrencileri için matematik kayg1 ölçeği. Furat Üniversitesi. Fen ve Mühendislik Bilimleri Dergisi, 17, 442-448.

Bloom, B.S. (1998). İnsan nitelikleri ve okulda öğrenme (Çev: D. A. Özçelik). İstanbul: MEB Yayınları.

Bourne, E. J. (1995). The anxiety and phobia workbook. (2nd Ed). Oakland, CA: New Harbiner Publications, Inc.

Brush, L. R. (1978). A validation study of the mathematical anxiety rating scale. Educational and Psychologcal Measurement, 38(2), 485-490. https:/ / doi.org/10.1177/001316447803800236

Büyüköztürk, Ş. (2012). Sosyal bilimler için veri analizi el kitabı (7.baskı). Ankara: Pegem Akademi Yayıncılık.

Büyüköztürk, Ş., Çokluk, Ö. ve Şekercioğlu G. (2012). Sosyal bilimler için çok değişkenli 
istatistik (PegemA Yayıncllik). Ankara.

Campbell K. T., and Evans C. (1997). Gender issues in the classroom: A comparison of mathematics anxiety. Education, 117(3), 332-339.

Cooper, S. E., and Robinson, D. A. (1991). The relationship of mathematics selfefficacy beliefs to mathematics anxiety and performance. Measurement and Evaluation in Counseling and Development, 24, 5-11.

Çokluk, Ö, Şekercioğlu, G., and Büyüköztürk, Ş. (2014). Sosyal bilimler için çok değişkenli istatistik (SPSS ve LISREL uygulamaları). Ankara: Pegem Yayıncılık.

Dede, Y. ve Dursun, Ş. (2008). İlköğretim ikinci kademe öğrencilerinin matematik kayg1 düzeylerinin incelenmesi. Eğitim Fakültesi Dergisi, 21(2), 295-312.

Delice, A., Ertekin, E., Aydın, E. ve Dilmaç, B. (2009). Öğretmen adaylarının matematik kaygısı ile bilgibilimsel inançları arasındaki ilişkinin incelenmesi, Uluslararası Insan Bilimleri Dergisi, 6(1), 361-375.

Doruk, M. ve Kaplan, A. (2012). Sınıf ve ilköğretim matematik öğretmeni adaylarının matematik kaygılarının incelenmesi, Kastamonu Ĕ̆itim Dergisi, 21(4), 15051522.

Dreger, R. M. ve Aiken, L. R. Jr. (1957). The identification of number anxiety in a college population. Journal of Educational Psychology, 46(6), 344-351. https:/ / doi.org/10.1037/t06699-000

Eldemir, H. H. (2006). Sını öğretmeni adaylarının matematik kaygısının bazı psiko-sosyal değişkenler açısından değerlendirilmesi (Yayımlanmamış Yüksek Lisans Tezi, Cumhuriyet Üniversitesi, Sosyal Bilimler Enstitüsü, Sivas), https:/ / tez.yok.gov.tr/ adresinden edinilmiştir.

Elmas, S. H. (2010). Sını öğretmeni adaylarının matematik öğretmeye yönelik kaygı düzeyleri ve bu kaygıya neden olan faktörler (Yayınlanmamış Yüksek Lisans Tezi, Kocatepe Üniversitesi, Sosyal Bilimler Enstitüsü, Afyon), https://tez.yok.gov.tr/ adresinden edinilmiştir.

Ersoy, Y. (2003). Teknoloji destekli matematik eğitimi-1; gelişmeler, politikalar ve stratejiler. İlköğretim-Online 2(1), 18-27.

Ertürk, E. ve Keçecioğlu, T. (2012). Çalışanların iş doyumları ile mesleki tükenmişlik düzeyleri arasındaki ilişkiler: Öğretmenler üzerine örnek bir uygulama. Ege Akademik Bakış, 12(1), 39-52. https:/ / doi.org/10.21121/eab.2012119545

Fee-Fulkerson, K. C. (1983). Cognitions and performance of high and low math anxious college men and women. Dissertation Abstracts International, 43(11-B), 3729-3730.

Frank, M. L. (1990). What myths about mathematics are held and conveyed by teachers? The Arithmetic Teacher, 37(5), 10-12.

https:/ / doi.org/10.5951/AT.37.5.0010

Freeman, C. L. (1982). The effects of a mathematics anxiety reduction model on the students in a college level basic mathematics skill course. Dissertation Ahstracts International, 43: 1456-1457.

Gardner, L.E., and Leak, G. K. (1994). Characteristics and correlates of teaching anxiety among college psychology teachers. Teaching of Psychology, 21(1), 2832.

Gresham, G. (2008) Mathematics anxiety and mathematics teacher efficacy in 
elementary pre-service teachers, Teaching Education, 19(3), 171-184. https:/ / doi.org/10.1080/10476210802250133

Gilroy, M. (2002). Waking up students math/science attitudes and achivement. The Education Digest, 68(4), 39-44.

Girgin, G. (1995). İlkokul öğretmenlerinde meslekten tükenmişliğin gelişimini etkileyen değişkenlerin analizi ve bir model önerisi. (Doktora Tezi, Dokuz Eylül Üniversitesi, Sosyal Bilimler Enstitüsü, İzmir), https:/ / tez.yok.gov.tr/ adresinden edinilmiştir.

Gündüz, B. (2005). İlköğretim öğretmenlerinde tükenmişlik. Mersin Üniversitesi Ĕ̆itim Fakültesi Dergisi, 1(1), 152-166.

Gürbüz, R. ve Yıldırım, K., (2016). An investigation of mathematics anxiety of primary school teachers, Turkish Journal of Computer and Mathematics Education, 7(3), 536-552. https:// doi.org/10.16949/turkbilmat.277870

Hannula, M. S. (2002). Attitudes toward mathematics: Emotions, expectations, and values. Educational Studies in Mathematics, 49(1), 25-46.

Harper, N. W., and Daane, C. J. (1998). Causes and reduction of mathematics anxiety in preservice elementary teachers. Action in Teacher Education, 19(4), 29-38. https:// doi.org/10.1080/01626620.1998.10462889

Hembree, R. (1990). The nature, effects, and relief of mathematics anxiety. Journal for Research in Mathematics Education. 33-46. https:// doi.org/10.2307/749455

Jackson, C. D., and Leffingwell, J. R. (1999). The role of the instructors in creating math anxiety in students from kindergarten through college. The Mathematics Teacher, 92(7), 583-586.

Kacar, M. ve Sarıçam, H. (2015). Sınıf öğretmen adaylarının üstbiliş farkındalıkları ile matematik kaygı düzeyleri üzerine bir çalışma. Trakya Üniversitesi Ĕ̆itim Fakültesi Dergisi, 5(2), 137-152.

Karasar, N. (2013). Bilimsel araştırma yöntemi. Ankara: Nobel Akademik Yayıncılık.

Kilmen, S. ve Demirtaşlı, N. Ç. (2009). Sınıf öğretmenlerinin ölçme ve değerlendirme ilkelerini uygulama düzeylerine ilişkin görüşleri. Ankara Üniversitesi Ĕ̆itim Bilimleri Fakültesi Dergisi, 42(2), 27-54.

Kutluca, T., Alpay, F. N. ve Kutluca, S. (2015). 8. sınıf öğrencilerinin matematik kayg1 düzeylerine etki eden faktörlerin incelenmesi, Dicle Üniversitesi Ziya Gökalp Ĕ̆itim Fakültesi Dergisi, 25, 202-214.

Ling, J.L. (1982), A factor analytic study of mathematics anxiety, Doctoral dissertation, Virginia: Virginia Polytechnic Institute and State University.

Linn, M. C., and Kessel, C. (1996). Success in mathematics: increasing talent and gender diversity among college majors. CBMS Issues in Mathematics Education, 6, 101-144. https://doi.org/10.1090/cbmath/006/05

Martinez, J. G. R. (1987). Preventing math anxiety: A prescription. Academic Therapy, 23(2), 117-125.

McAnallen, R. R. (2010). Examining mathematics anxiety in elementary classroom teachers. University of Connecticut, 2010.

Mcleod, D. B., and Adams, V. M. (Eds.). (2012). Affect and mathematical problem solving: A New Perspective. New York: Springer-Verlag.

Miller, L. D., and Mitchell, C. E. (1994). Mathematics anxiety and alternative methods of evaluation. Journal of Instructional Psychology, 21(4), 353-358. 
Mutlu, Y. ve Söylemez, İ. (2018). İlkokul 3. ve 4. sınıf çocukları için matematik kayg1 ölçeği: Güvenirlik ve geçerlik çalışması. Ekev Akademi Dergisi, 22(73), 429-440. https:/ / doi.org/10.17753/Ekev839

Nolting, P.D. (2011). Math study skills workbook. (Fourth Edition). South Melbourne: Cengage Learning.

Olson, J. (1985). Causes and correlates of mathematics anxiety and mathematics achievement: A path analytic approach. Doctoral dissertation, The University of Nebraska.

Peker, M. (2009a). The use of expanded microteaching for reducing pre-service teachers' teaching anxiety about mathematics. Scientific Research and Essay, 4(9), 872-880.

Peker, M. (2009b). Pre-service teachers' teaching anxiety about mathematics and their learning styles. Eurasia Journal of Mathematics, Science E Technology Education, 5(4), 335-345. https:// doi.org/10.12973/ejmste/ 75284

Peker, M. (2009c). The effects of an instruction using problem solving strategies in mathematics on the teaching anxiety level of the pre-service primary school teachers. The New Educational Review, 19(3-4), 95-114.

Peker, M. ve Ertekin, E. (2011). The relationship between mathematics teaching anxiety and mathematics anxiety. The New Educational Review, 23(1), 213-226.

Peker, M. ve Mirasyedioğlu Ş. (2003). Lise 2. sinıf öğrencilerinin matematik dersine yönelik tutumları ve başarıları arasındaki ilişki. Pamukkale Üniversitesi Eğitim Fakültesi Dergisi, 14(14), 157-166.

Peker, M. ve Halat, E. (2008). The pre-service elementary school teachers'mathematics teaching anxiety and gender. The European Conference on Educational Research, 10-12 September, Goteborg, Sweden.

Perry, A. B. (2004). Decreasing mathematics anxiety in college students. College Student Journal, 38(2), 321-324.

Richardson, F. C., and Suinn, R. M. (1972). The mathematics anxiety rating scale: psychometric data. Journal Of Counseling Psychology, 19(6), 551-554. https:/ / doi.org/10.1037/t02345-000

Sakal, M. (2015). İlkokul 4. Sını öğrencilerinin bazı psiko-sosyal değişkenlere göre matematik kaygısının incelenmesi. (Yüksek Lisans Tezi. Dokuz Eylül Üniversitesi, Eğitim Bilimleri Enstitüsü, İzmir), https:/ / tez.yok.gov.tr/ adresinden edinilmiştir.

Scovel, T. (1978). The effect of affect on foreign language learning: A review of the anxiety research. Language Learning, 28(1), 129-142. https:/ / doi.org/10.1111/j.1467-1770.1978.tb00309.x

Şentürk, B. (2010). İlköğretim beşinci sınıf öğrencilerinin genel başarıları, matematik başarıları, matematik dersine yönelik tutumları ve matematik kaygıları arasındaki ilişki (Yüksek Lisans Tezi, Afyon Kocatepe Üniversitesi, Sosyal Bilimler Enstitüsü, Afyon), https://tez.yok.gov.tr/ adresinden edinilmiştir.

Shields, D. J. (2006). Causes of math anxiety: The student perspective. Doctoral dissertation, Indiana University of Pennyslvania.

Taşdemir, C. (2015). Ortaokul öğrencilerinin matematik kayg1 düzeylerinin incelenmesi. Batman Üniversitesi Yaşam Bilimleri Dergisi, 5(1), 1-12.

Tatar, E., Zengin Y. ve Kağızmanlı T. B. (2016). Öğretmen adaylarının matematik 
öğretmeye yönelik kaygı düzeylerinin incelenmesi, Kuramsal Eğitimbilim Dergisi, 9(1), 38-56.

Tobias, S. (1990). Math Anxiety: An Update. Nacada Journal, 10(1), 47-50. https:/ / doi.org/10.12930/0271-9517-10.1.47

Uusimaki, L., and Nason, R. (2004). Causes underlying pre-service teachers' negative beliefs and anxieties about mathematics. International Group for the Psychology of Mathematics Education, 4, 369-376.

Üldaş, İ. (2005). Öğretmen ve öğretmen adaylarma yönelik matematik kaygı ölçeği (MKÖ-

Ö)'nin geliştirilmesi ve matematik kaygısına ilişkin bir değerlendirme (Yayınlanmamış Yüksek Lisans Tezi, Marmara Üniversitesi, Eğitim Bilimler Enstitüsü, İstanbul), https:// tez.yok.gov.tr/ adresinden edinilmiştir.

Ünlü, E. (2007). İlkoğretim okullarındaki üçüncü, dördüncü ve beşinci sınıf ögrrencilerinin matematik dersine yonelik tutum ve ilgilerinin belirlenmesi, Dumlupınar Üniversitesi Sosyal Bilimler Dergisi, 19, 129-148.

Vinson, B. M. (2001). A Comparison of preservice teachers' mathematics anxiety before and after a methods class emphasizing manipulatives. Early Childhood Education Journal, 29(2), 89-94.

Wiggins, J. D. (1984). Personality-environmental factors related job satisfaction of school counselors. Vocational Guidance Quarterly, 3(8), 171-177. https:/ / doi.org/10.1002/j.2164-585X.1984.tb01092.x

Wilder, S. (2012). Gender differences in factors pertaining to math anxiety among college students, Unpublished Doctoral Dissertation, The University of Akron.

Wood, E. (1988). Mathematics anxiety and elementary teachers: what does the research tell us? For The Learning of Mathematics, 8(1), 8-13.

Woodard, T. (2004). The effects of math anxiety on post-secondary developmental students as related to achivement, Gender and Age. Inquiry, 9(1), 1-5.

Yenihayat, S.A. (2007). İlköğretim öğrencilerinin matematik kaygısı ile öğretmen tutumları arasındaki ilişkinin değerlendirilmesi (Yüksek lisans tezi, Yeditepe Üniversitesi Sosyal Bilimler Enstitüsü, İstanbul), https:/ / tez.yok.gov.tr/ adresinden edinilmiştir.

Yenilmez, K. ve Özbey N. (2006). Özel okul ve devlet okulu öğrencilerinin matematik kaygı düzeyleri üzerine bir araştırma. Uludağ Üniversitesi Eğitim Fakültesi Dergisi, 19(2), 431-448.

Yıldırım, K. (2013). Sını öğretmenlerinin matematik kaygı düzeylerinin incelenmesi (Yüksek Lisans Tezi, Adıyaman Üniversitesi, Fen Bilimleri Enstitüsü, Adiyaman), https:/ / tez.yok.gov.tr/ adresinden edinilmiştir.

Yıldırım, K. ve Gürbüz, R. (2017). Öğretmenlere yönelik matematik kaygı ölçeği geliştirme çalışması. Eğitimde Kuram ve Uygulama. 13(3), 392-410. https:/ / doi.org/10.17244/eku.331901

Yüksel-Şahin, F. (2008). Mathematics anxiety among 4th and 5th grade Turkish elementary school students. International Electronic Journal of Mathematics Education, 3(3), 179-192.

Zettle, R. D., and Raines, S. J. (2000). The Relationship of trait and text anxiety with mathematics anxiety. College Student Journal, 34(2), 246.

Zopp, M. (1999). Math anxiety, the adult student, and the community college, Unpublished Doctoral Dissertation, Nothern Illionis University. 


\section{Summary}

\section{Introduction}

This research was conducted to investigate the mathematics anxiety of primary school teachers and the significance of these anxieties according to various variables, additionally to score the mathematics anxiety of the students and determine their significance according to various variables.

\section{Method}

This research was designed as a correlational study by survey model to determine the relationship between the mathematics anxiety of primary school teachers and students. This correlational study is conducted by survey model to determine the relationship between the mathematics anxiety of primary school teachers and their students. The universe of the study consists of the 3rd and 4th grade teachers (530 teachers) working in the city center of Antalya in the 2018-2019 academic year and the 3rd and 4th grade students (15900 students) of the primary schools where these teachers teach. In the study, the "Mathematics Anxiety Scale for Teachers" developed by Yıldırım and Gürbüz (2017) to measure the mathematics anxiety of primary school teachers, and the "Elementary School Students' Mathematics Anxiety Scale" developed by Mutlu and Söylemez (2018) to measure the mathematics anxiety of primary school students were used. In the study, a statistical analysis program was used to analyze the data of the scales applied to 300 primary school teachers and 3380 primary school 3rd and 4th grade students.

\section{Results}

When the General Findings Regarding Mathematics Anxiety of Primary School Teachers were examined, it was determined that the total anxiety scores of primary school teachers towards teaching mathematics were generally lower according to the Teacher Anxiety Scale score ranges. The anxiety that includes the situations about the Nature of Mathematics and arising from the structure of mathematics itself was found low as a result of the analysis. The highest average anxiety score belongs to the Technology/Mathematics Based Anxiety sub-factor. When the Findings Regarding the Evaluation of Mathematics Anxiety Scores of Primary School Teachers in terms of the gender variable were examined, a significant difference was found in favor of males in the sub-factor Anxiety Arising from the Nature of Mathematics. There was no significant difference by gender in primary school teachers' Self-efficacy Anxiety, Environmental Anxiety, Technology/Mathematics Based Anxiety, Mathematical Communication Anxiety, and Total Anxiety, except for the sub-factor Anxiety Originating from the Nature of Mathematics. Male primary school teachers are more Anxious About the Nature of Mathematics than their female colleagues. When the Findings Regarding the Evaluation of Mathematics Anxiety Scores of Primary School Teachers in Terms of Education Level Variable were examined; there was no significant difference between Primary school teachers' associate degreeundergraduate-graduate graduation levels and the Anxiety Originating from the Nature of Mathematics, Self-Efficacy Anxiety, Technology/Mathematics Based Anxiety, Mathematical Communication Anxiety and Environmental Anxiety sub- 
factor scores and total anxiety scores ( $p>$.05). The fact that primary school teachers have an associate, undergraduate and graduate education does not affect the mathematics anxiety scores of teachers. When the Findings Regarding the Evaluation of Mathematics Anxiety Scores of Primary School Teachers in Terms of the Field of Graduation Variable were examined, a significant difference was found in the SelfEfficacy Anxiety sub-factors according to the field from which the participants graduated. The data were analyzed with the Post Hoc Tukey test in order to determine among which groups that the difference is occurred. This difference was between primary school teaching graduates and other teaching department graduates, and the anxiety scores of other teaching department graduates are higher. A significant difference was found in the Total Anxiety scores according to the field the primary school teachers graduated from. When the Findings of the Primary School Teachers According to the Relationship Between Mathematics Anxiety Scores and Their Seniority were examined, a positive significant relationship was found between the math anxiety scores of the primary school teachers and their seniority in the factors of Anxiety Originating from the Nature of Mathematics, Self-Efficacy Anxiety, Technology/Mathematics Based Anxiety, Mathematical Communication Anxiety and Total Anxiety. According to the Findings Regarding the Evaluation of the Anxiety Scores of Primary School Students, the Avoidance-Worrying subscale is at a low level depending on scale grading scores. Negative Attitude Anxiety is moderate according to scale rating scores. The Positive Emotions factor is high depending on the scale evaluation scores. The highest mean value belongs to the Positive Emotions sub-factor. According to Findings Regarding the Evaluation of Mathematics Anxiety Scores of Primary School Students in Terms of Gender Variable, in accordance with t-test results, a significant difference in favor of girls was found in the Avoidance-Worrying subfactor of primary school students. No significant difference was found in Positive Emotions and Negative Attitude sub-factors by gender. Students' Positive Emotions and Negative Attitude scores towards mathematics do not constitute a statistically significant difference in terms of gender. According to the findings of the Evaluation of the Relationship between Primary School Teachers' Mathematics Anxiety Scores and Students' Mathematics Anxiety Scores, there is a significant correlational relationship between the primary school teachers' Self-Efficacy Anxiety and the Negative Attitude sub-factor of their students. Accordingly, it can be said that the general communication anxieties of primary school teachers towards mathematics lessons cause avoidance and worry in their students.

\section{Discussion and Conclusion}

In line with the findings regarding the research question about the mathematics anxiety of primary school teachers, the average of Total Anxiety scores of primary school teachers is 2.14. When the sub-factors of the study are examined, it is seen that only the Anxiety Originating from the Nature of Mathematics and Mathematical Communication Anxiety are below the average. The reason for this is that primary school teachers think that their mathematics teaching in classes is useful and that mathematics has its own customary language of communication. It can be said that the reasons for the high levels of Self-Efficacy Anxiety, Environmental Anxiety and Technology/Mathematics Based Anxiety are that teachers' content knowledge of 
mathematics is not sufficient and the negative correlation between the case that age of the primary school teachers who constitute the sample is generally older and their usage level of technological devices. It was observed that the anxiety scores of the primary school teachers did not differ significantly by gender except for merely one factor. According to the results of the analysis regarding the evaluation of the mathematics anxiety scores of the primary school teachers in terms of the grade level variable, the Total Anxiety score and the Environmental Anxiety score differ significantly between the 4th grade teachers and the 3rd grade teachers, and the anxiety scores of the 4 th grade teachers are higher. According to this result, it can be said that 4th grade teachers experience more Total Anxiety and Environmental Anxiety than their 3rd grade colleagues. According to the analysis results regarding the evaluation of the mathematics anxiety scores of the primary school teachers in terms of the education level variable, no significant difference was found between the mathematics anxiety scale sub-factors and Total Anxiety scores according to the associate / undergraduate/graduate levels of the primary school teachers. When the relationship between the mathematics anxiety scores of the primary school teachers and their seniority was evaluated, it was seen that there was a significant and positive relationship between mathematics anxiety and seniority, except for only one subfactor. It can be said that with the increase in the seniority of the teachers, their math anxiety increased. According to the results obtained from the research findings, there is a significant relationship between the primary school teachers 'Self-Efficacy Anxiety and their students' Negative Attitude sub-factor. Additionally, there is a significant relationship between the Mathematical Communication Anxiety sub-factor of the primary school teachers and the Avoidance-Worrying Anxiety of their students. In addition to these, a significant relationship was found between the Total Anxiety scores of the primary school teachers and the avoidance-worrying sub-factor of their students. If math anxiety that starts in the first stage of elementary education cannot be prevented, it is inevitable that these worries will continue to increase in the future years. Therefore, more quantitative and qualitative research can be conducted on primary school students about their math anxiety. Educational studies can be made to prevent anxiety of teachers.

\section{Araştırmanın Etik Taahhüt Metni}

Yapılan bu çalışmada bilimsel, etik ve alıntı kurallarına uyulduğu; toplanan veriler üzerinde herhangi bir tahrifatın yapılmadığı, karşılaşılacak tüm etik ihlallerde "Cumhuriyet Uluslararası Eğitim Dergisi ve Editörünün" hiçbir sorumluluğunun olmadığı, tüm sorumluluğun Sorumlu Yazara ait olduğu ve bu çalışmanın herhangi başka bir akademik yayın ortamına değerlendirme için gönderilmemiş olduğu sorumlu yazar tarafından taahhüt edilmiştir.

\section{Authors' Biodata/ Yazar Bilgileri}

Sevgi YAVUZ, Millî Eğitim Bakanlığı'nda matematik öğretmeni olarak çalışmaktadır. Akdeniz Üniversitesi Eğitim Bilimleri Enstitüsü'nde Yüksek Lisans Tez çalışmasını tamamlamıştır. 
Sevgi Yavuz is a mathematics teacher at Ministry of National Education of Turkey. He completed his Master's thesis in the Institute of Educational Sciences, Akdeniz University, Antalya.

Ali ÖZKAYA, Akdeniz Üniversitesinde Eğitim Fakültesi'nde doktor öğretim üyesi olarak görev yapmaktadır. Doktorasını Gazi Üniversitesi Eğitim Bilimleri Enstitüsü'nde tamamlamıştır. İlgi duyduğu çalışma konuları öğretmen eğitimi, öğretim programları ve gerçekçi matematik eğitimidir.

Ali Özkaya is an assistant professor in Education Faculty of Akdeniz University, Antalya, Turkey. He completed his doctoral degree at Educational Sciences Institute Gazi University, Turkey. His research interests include Mathematics Teacher Education, Instruction Program and Realistic Mahhematics Education. 